УДК 159.9

DOI https://doi.org/10.32838/2709-3093/2021.5/07

\title{
Шашенков Д.М.
}

Національний університет цивільного захисту України

\section{ГЕНЕЗА СПЕЦІАЛЬНОСТІ 19.00.09 - «ПСИХОЛОГІЯ ДІЯЛЬНОСТІ В ОСОБЛИВИХ УМОВАХ»}

Стаття спрямована на розкриття історичного поступу спеціальності 19.00.09 - «Психологія діяльності в особливих умовах», наукових здобутків, отриманих дослідниками в ії межах, а також розгляд проблем методологічного характеру, які залишилися поза увагою науковців. Під час розгляду генези спеціальності 19.00 .09 використані: метод тематичної класифікації дисертацій, контент-аналіз, синтез і оглядово-аналітичний метод. Зазначені методи дозволили визначити й охарактеризувати: проблемне поле спеціальності (особливості дій фахівиів в екстремальних ситуаціях, вплив екстремальних ситуацій на спеціалістів сектору безпеки й оборони, їхній професійно-психологічний відбір, екстремально-психологічна підготовка, а також особливості саморегуляиії; психодіагностична, психопрофілактична та реабілітаційна робота з відповідними спеціалістами, встановлення їхньої психологічної готовності до дій в екстремальних умовах, а також психологічна допомога співробітникам, які пережили психотравмуючий вплив у процесі виконання професійних обов 'язків; особливості взаємодї фахівиів із громадянами, які перебувають у зміненому, кризовому або загрозливому психічному стані, психологія запобігання, припинення групових порушень громадського порядку та масових заворушень) та міждисииплінарні зв'язки психології діяльності в особливих умовах (з біологічними, технічними, історичними, юридичними, педагогічними, медичними, військовими, соціологічними наукали, начіональною безпекою та державним управлінням), коло професій, на які поширюються результати досліджень за вищезазначеною спещіальністю (пожежні, рятувальники, співробітники правоохоронних та спеціалізованих органів, військовослужбовиі, космонавти, пілоти, моряки, охорониі, шахтарі, водії, спортсмени). Перспективу дослідження вбачаємо в більш трунтовному опращюванні здобутків спеціальності «Психологія діяльності в особливих умовах», метою якого є не тільки вирішення методологічних проблем, але й висвітлення провідних та перспективних наукових напрямів у межах заявленої спеціальності.

Ключові слова: психологія діяльності в особливих умовах, методологія, дисертаційні дослідження, сектор безпеки та оборони України, тематична класифікація.

Постановка проблеми. У сучасних умовах глобалізації та технологізації небувалого піднесення досягають всі сфери наукового знання. Технічний та науковий прогрес можливий лише за умови детального та систематичного опанування наявних надбань, адже майбутнє засноване на минулому.

Вищезазначене стосується й області нашого наукового інтересу - спеціальності 19.00.09 «Психологія діяльності в особливих умовах», адже, зважаючи на досвід історичного розвитку спеціальності, можна більш конкретно оцінювати сучасний стан і прогнозувати шляхи підвищення істинності та значущості психологічних досліджень для сектору безпеки й оборони України. Зокрема, наукові пошуки в означеному напрямі дозволять нам вирішити низку нагальних методологічних проблем у межах спеціальності: розробити періодизацію, визначити закономірності й особливості процесу розвитку психологічних досліджень, встановити їх сутність і структуру, здійснити наукову характеристику спрямованості методів та принципів досліджень за спеціальністю, а також створити модель дослідницької діяльності екстремального психолога.

Аналіз останніх досліджень і публікацій. Вітчизняна психологія отримала самостійний статус у 1968 р., коли була відкрита нова наукова галузь - психологічні науки. За роки існування СРСР перелік спеціальностей у межах галузі неодноразово змінювався (див. табл. 1).

Згідно $з$ даними, що подані в таблиці 1, спеціальність 19.00.09 - «Психологія діяльності в особливих умовах» отримала офіційний статус лише в 1972 р. й у СРСР мала назву «Психологія праці в особливих умовах».

У незалежній Україні галузь «Психологічні науки» зазнала трансформацій. Так, наказом ВАК № 86 від 13 березня 1997 р. [1] було затверджено новий перелік спеціальностей, який зазнав змін у наказі ВАК України № 288 від 10 червня 1999 р. 
«Про затвердження Переліку спеціальностей, за якими проводиться захист дисертацій на здобуття наукових ступенів кандидата наук і доктора наук, присудження наукових ступенів і присвоєння вчених звань» [2] (див. табл. 2).

\section{Перелік наукових спеціальностей у радянській психології (1968-1991 рр.)}

\begin{tabular}{|c|c|}
\hline $\begin{array}{c}\text { Шифр } \\
\text { спеціальності }\end{array}$ & Спеціальність \\
\hline \multicolumn{2}{|r|}{$1968 \mathrm{p}}$. \\
\hline $\begin{array}{l}21960 \\
21961 \\
21962 \\
21963 \\
21964 \\
\end{array}$ & $\begin{array}{l}\text { Загальна психологія } \\
\text { Психофізіологія } \\
\text { Психологія праці } \\
\text { Інженерна психологія } \\
\text { Медична психологія } \\
\end{array}$ \\
\hline $\begin{array}{l}21965 \\
21966 \\
21967 \\
21968 \\
21969 \\
21970\end{array}$ & $\begin{array}{l}\text { Соціальна психологія } \\
\text { Судова психологія } \\
\text { Дитяча та педагогічна психологія } \\
\text { Зоопсихологія } \\
\text { Військова психологія } \\
\text { Спеціальна психологія } \\
\end{array}$ \\
\hline \multicolumn{2}{|r|}{$1972 p$} \\
\hline $\begin{array}{l}19.00 .01 \\
19.00 .02 \\
19.00 .03 \\
19.00 .04 \\
19.00 .05 \\
19.00 .06 \\
19.00 .07 \\
19.00 .08 \\
19.00 .09 \\
19.00 .10 \\
\mathbf{1 9 . 0 0 . 1 1} \\
20.02 .02\end{array}$ & $\begin{array}{l}\text { Загальна психологія } \\
\text { Психофізіологія } \\
\text { Психологія праці } \\
\text { Медична психологія } \\
\text { Соціальна психологія } \\
\text { Юридична психологія } \\
\text { Дитяча та педагогічна психологія } \\
\text { Зоопсихологія } \\
\text { Військова психологія } \\
\text { Спеціальна психологія } \\
\text { Психологія праці в особливих } \\
\text { умовах } \\
\text { Військова педагогіка та психологія }\end{array}$ \\
\hline \multicolumn{2}{|r|}{$1977 p}$. \\
\hline $\begin{array}{l}19.00 .01 \\
19.00 .02 \\
19.00 .03 \\
19.00 .04 \\
19.00 .05 \\
19.00 .06 \\
19.00 .07 \\
19.00 .10 \\
\mathbf{1 9 . 0 0 . 1 1}\end{array}$ & $\begin{array}{l}\text { Загальна психологія; історія } \\
\text { психології } \\
\text { Психофізіологія } \\
\text { Психологія праці; інженерна } \\
\text { психологія } \\
\text { Медична психологія } \\
\text { Соціальна психологія } \\
\text { Юридична психологія } \\
\text { Вікова та педагогічна психологія } \\
\text { Спеціальна психологія } \\
\text { Психологія праці в особливих } \\
\text { умовах }\end{array}$ \\
\hline \multicolumn{2}{|r|}{$1988 p$} \\
\hline $\begin{array}{l}19.00 .01 \\
19.00 .02 \\
19.00 .03 \\
19.00 .04 \\
19.00 .05 \\
19.00 .06 \\
19.00 .07 \\
19.00 .10 \\
\mathbf{1 9 . 0 0 . 1 4} \\
05.02 .20\end{array}$ & $\begin{array}{l}\text { Загальна психологія; історія } \\
\text { психології } \\
\text { Психофізіологія } \\
\text { Психологія праці; інженерна } \\
\text { психологія } \\
\text { Медична психологія } \\
\text { Соціальна психологія } \\
\text { Юридична психологія } \\
\text { Вікова та педагогічна психологія } \\
\text { Спеціальна психологія } \\
\text { Психологія праці в особливих } \\
\text { умовах } \\
\text { Ергономіка }\end{array}$ \\
\hline
\end{tabular}

Таблиця 2

Перелік наукових спеціальностей в галузі вітчизняної психології (1997-1999 рр.)

\begin{tabular}{|c|c|}
\hline $\begin{array}{c}\text { Шифр } \\
\text { спеціальності }\end{array}$ & Спеціальність \\
\hline \multicolumn{2}{|r|}{$1997 p}$. \\
\hline $\begin{array}{l}19.00 .01 \\
19.00 .02 \\
19.00 .03 \\
19.00 .04 \\
19.00 .05 \\
19.00 .06 \\
19.00 .07 \\
19.00 .08 \\
\mathbf{1 9 . 0 0 . 0 9}\end{array}$ & $\begin{array}{l}\text { Загальна психологія; історія } \\
\text { психології } \\
\text { Психофізіологія } \\
\text { Психологія праці; інженерна } \\
\text { психологія } \\
\text { Медична психологія } \\
\text { Соціальна психологія } \\
\text { Юридична психологія } \\
\text { Педагогічна та вікова психологія } \\
\text { Спеціальна психологія } \\
\text { Психологія праці в особливих } \\
\text { умовах }\end{array}$ \\
\hline \multicolumn{2}{|r|}{$1999 p}$. \\
\hline $\begin{array}{l}19.00 .01 \\
19.00 .02 \\
19.00 .03 \\
19.00 .04 \\
19.00 .05 \\
19.00 .06 \\
19.00 .07 \\
19.00 .08 \\
\mathbf{1 9 . 0 0 . 0 9} \\
19.00 .10\end{array}$ & $\begin{array}{l}\text { Загальна психологія; історія } \\
\text { психологї } \\
\text { Психофізіологія } \\
\text { Психологія праці; інженерна } \\
\text { психологія } \\
\text { Медична психологія } \\
\text { Соціальна психологія; психологія } \\
\text { соціальної роботи } \\
\text { Юридична психологія } \\
\text { Педагогічна та вікова психологія } \\
\text { Спеціальна психологія } \\
\text { Психологія діяльності в } \\
\text { особливих умовах } \\
\text { Організаційна психологія; } \\
\text { економічна психологія }\end{array}$ \\
\hline
\end{tabular}

У 1999 р. назва спеціальності змінилася i набула сучасного вигляду - «Психологія діяльності в особливих умовах», а дещо пізніше постановою президії ВАК України від 9 листопада 2006 р. № 40-06/10 [3] був затверджений сучасний паспорт спеціальності 19.00.09.

Переломним моментом історичного поступу спеціальності стала постанова Кабінету Міністрів України від 29 квітня 2015 р. № 266 «Про затвердження переліку галузей знань і спеціальностей, за якими здійснюється підготовка здобувачів вищої освіти».

Згідно 3 даною постановою, спеціальність «Психологія діяльності в особливих умовах» була скасована, а підготовка здобувачів вищої освіти перенесена в галузь знань 05 - «Соціальні та поведінкові науки» (код спеціальності - 053 «Психологія») [4].

Постановка завдання. Мета статті - теоретикометодологічне дослідження історичного поступу спеціальності 19.00.09 - «Психологія діяльності в особливих умовах», іiі наукових здобутків. 
Завдання статті: визначити предмет, проблемне поле та межі вітчизняної психології діяльності в особливих умовах.

Основними методами дослідження стали: метод тематичної класифікації дисертацій, який дозволив проаналізувати дисертаційні дослідження та згрупувати їх за категоріями; контентаналіз, за допомогою якого виявлені ключові слова в усіх 232 дисертаціях, захищених за весь період існування спеціальності, та провести їх класифікацію; синтез і оглядово-аналітичний метод, які дозволили вивчити напрацювання в зазначеній галузі психології, провести огляд і аналіз науковотеоретичного доробку, який сформувався на цей час у межах зазначеної спеціальності.

Виклад основного матеріалу дослідження. У результаті дослідження історичного шляху спеціальності 19.00.09 констатуємо, що в сучасній психологічній науці остаточно так і не було обговорено та визначено предмет, проблемне поле та границі вітчизняної психології діяльності в особливих умовах. Колізія між назвою (особливі умови) та формулою спеціальності (екстремальні умови) дозволяла включати проблеми особистості та групи в екстремальних ситуаціях і діяльності в умовах впливу стрес-факторів підвищеної інтенсивності в інші області психологічного знання зі схожими або ідентичними предметами. На підтвердження наведемо деякі публікації:

- навчальний посібник «Психологія катастроф» (П. Смирнов, І. Мосягин, С. Маруняк);

- навчальний посібник «Психологічний захист у надзвичайних ситуаціях» (Л. Михайлов, Т. Маликова, О. Шатровой, А. Михайлов, В. Соломин);

- навчальний посібник «Кризова психологія» (Ю. Александров, Л. Гонтаренко, О. Свсюков, А. Куфлієвський, С. Лєбєдєва, С. Миронець, О. Назаров, Я. Овсяннікова, Н. Оніщенко, Л. Перелигіна, І. Поляков, Ю. Приходько, В. Садковий, О. Тімченко, Д. Титаренко, В. Христенко);

- навчальний посібник «Психологія праці у звичайних та екстремальних умовах» (М. Корольчук, В. Корольчук, С. Миронець, О. Тімченко, В. Осьодло, Г. Ржевський, К. Максименко).

Отже, для опису умов, що характеризуються особливим значенням параметрів, які є важливими для життєдіяльності людини, використовується широке коло понять. Уживання більш конкретних понять (катастрофа, локальний збройний конфлікт, пожежа, стихійне лихо тощо) має точки перетину з абстрактними, узагальнюючими поняттями (кризові ситуачї̈, надзвичайні ситуачіï, критичні ситуації, важкі життєві ситуачії, екстре- мальні ситуащії, ризиконебезпечні ситуащиї тощо). Водночас «екстремальність» стає родовим поняттям для перелічених класів ситуацій. Саме тому вважаємо правильним сформований у вітчизняній науці підхід, згідно з яким для опису області психології діяльності в особливих умовах треба вживати термін «екстремальність», який найточніше описує предметну область спеціальності 19.00.09.

Коли говоримо про особливі умови професійної діяльності, варто враховувати ймовірну природу цього поняття, припускаючи, що ці умови у більшості людей спричинять екстремальні стани [4]. Однак нині в більшості класифікацій професій та професійних занять згадуються професії, які належать до екстремальних (професії особливого ризику, ризиконебезпечні професії) за умовами їх здійснення, але й дотепер не виділені формальні критерії віднесення професій до екстремальних. Наприклад, у класифікації професій Є. Клімова [6] фах пожежного належить до групи робіт у незвичних умовах поряд 3 антенником-щогловиком і водолазом. До другої групи, особливостями умов праці в якій є підвищена моральна відповідальність за життя та здоров'я людей (що також є невід'ємною умовою роботи пожежних), належить фах учителя [5].

Незаперечним $\epsilon$ те, що спектр професій, які можна віднести до екстремального профілю діяльності, є відносно нестабільним. Саме тому розробники паспорта спеціальності 19.00.09 під час визначення кола професій екстремального профілю керувалися аналізом умов професійної діяльності, орієнтувались на сукупність таких чинників, як: небезпека для життя та здоров'я (свого й інших); висока «ціна» помилки та відповідальність за результат діяльності; дефіцит часу й інформації для виконання професійних завдань; високий темп діяльності; новизна обстановки.

Вищезазначене дозволило окреслити коло професій та професійних занять, що можуть входити до складу груп, досліджуваних у межах спеціальності 19.00.09:

- пожежні та рятувальники;

- співробітники правоохоронних, спеціалізованих органів;

- військовослужбовці;

- космонавти;

- пілоти;

- моряки;

- охоронці;

- шахтарі;

- водії;

- спортсмени;

- працівники AEC; 
- особи, що стали жертвами подій, пов'язаних зі специфікою професійної діяльності зазначених категорій фахівців (ліквідація наслідків стихійного лиха, природних катаклізмів, боротьба 3 організованою злочинністю, корупцією, тероризмом, оперативно-розшукова діяльність, виконання миротворчої місії тощо).

Спробуємо дати відповідь на дискусійне питання про межі означеної спеціальності, адже це $\epsilon$ необхідним не тільки у зв'язку з потребою визначення проблемного поля, але й із погляду визначення вкладу спеціальності в розвиток сучасної вітчизняної та світової психології.

Питання виявлення міждисциплінарних зв'язків iз суміжними спеціальностями не було досить дослідженим, що призводило до того, що деякі кваліфікаційні наукові праці, дослідження, які фактично проводилися в межах заявленого паспорта спеціальності 19.00.09, захищалися за іншими спеціальностями. Наведемо декілька прикладів:

- у 1998 р. С. Яковенко захистив докторську дисертацію на тему: «Теорія і практика психологічної допомоги потерпілим від катастроф (на прикладі постчорнобильської ситуації)» за спеціальністю 19.00.01 - «Загальна психологія, історія психології»;

- у 2003 р. О. Тімченко захистив докторську дисертацію на тему: «Професійний стрес працівників органів внутрішніх справ України (концептуалізація, прогнозування, діагностика та корекція)» за спеціальністю 19.00.06 - «Юридична психологія»;

- у 2005 p. В. Стасюк за спеціальністю 19.00.05 - «Соціальна психологія, психологія соціальної роботи» захистив докторську дисертацію на тему: «Система соціально-психологічного забезпечення функціонування аеромобільних військових підрозділів в умовах збройних конфліктів»;

- у 2013 р. В. Осьодло захистив докторську дисертацію на тему: «Психологічні засади становлення суб'єкта військово-професійної діяльності» за спеціальністю 19.00.01 - «Загальна психологія, історія психології»;

- у 2019 р. О. Колесніченко за спеціальністю 19.00 .06 - «Юридична психологія» захистив докторську дисертацію на тему: «Психологія бойової травматизації військовослужбовців Національної гвардії України»;

- у 2020 р. О. Блінов захистив докторську дисертацію на тему: «Психологія бойового стресу» за спеціальністю 19.00.04 - «Медична психологія».

Аналогічна ситуація простежується і стосовно захисту дисертацій на здобуття наукового сту- пеня кандидата психологічних наук. Наприклад, за спеціальністю 19.00.06 - «Юридична психологія» захистилися: М. Логачов на тему: «Психологічна підготовка особового складу спеціальних підрозділів ОВС до дій в екстремальних ситуаціях»; В. Лефтеров на тему: «Психологічні причини загибелі та поранень працівників органів внутрішніх справ»; I. Слюсар на тему: «Посттравматичний стресовий розлад у працівників дорожньо-патрульної служби Державтоінспекції: профілактика, психологічна діагностика та корекція»; Л. Рибик на тему: «Теоретико-прикладні засади надання психологічної допомоги дружинам загиблих правоохоронців, загиблих при виконанні службових обов'язків» тощо.

Уважаємо, що означене питання треба і можна було б вирішити на основі виявлення міждисциплінарних зв'язків із суміжною спеціальністю.

Розглянемо дану тезу на прикладі спеціальностей 19.00.09 - «Психологія діяльності в особливих умовах» та 19.00.06 - «Юридична психологія».

Так, В. Васильєв уважає, що предмет юридичної психології становлять психічні закономірності діяльності й особистості людини в області правових відносин. Предметом юридичної психології В. Васильєв виділяє психологічні основи особистості та діяльності в умовах правового регулювання, систему «людина - право».

Низка ситуацій або умов, пов'язаних із правовим регулюванням, можуть бути особливими (екстремальними), що визначає загальну проблемну зону психології діяльності в особливих умовах та юридичної психології. Наприклад, механізми та динаміка переживання ситуації взяття в заручники.

3 іншого боку, проблеми, пов'язані зі специфічними умовами правозастосовної практики, не входять до цієї загальної зони. Наприклад, проблеми переживання пенітенціарного стресу в засуджених, питання оперативно-розшукової психології тощо. Саме тому ми вважаємо, що дослідження за такою проблематикою повинні перебувати в межах спеціальності 19.00.09 - «Психологія діяльності в особливих умовах»:

- психологічні особливості дій співробітників (працівників) правоохоронного органу (спеціальної служби, силової структури) в екстремальних ситуаціях;

- психологічний вплив екстремальних ситуацій на співробітників (працівників) правоохоронного органу (спеціальної служби, силової структури);

- професійно-психологічний відбір і екстремально-психологічна підготовка співробітників (працівників) правоохоронного органу (спеціаль- 
ної служби, силової структури) до дій в особливих умовах;

- психологічні особливості управління діяльністю правоохоронного органу (спеціальної служби, силової структури) в екстремальних умовах;

- психологічна готовність співробітників (працівників) правоохоронного органу (спеціальної служби, силової структури) до дій в екстремальних умовах службово-бойової (оперативно-службової) діяльності;

- психологічне забезпечення переговорної діяльності керівників правоохоронного органу (спеціальної служби, силової структури) в особливих умовах;

- психологія запобігання, припинення групових порушень громадського порядку та масових заворушень;

- психологічні особливості взаємодії співробітників (працівників) правоохоронного органу (спеціальної служби, силової структури) із громадянами, які перебувають у зміненому, кризовому або загрозливому психічному стані;

- питання психічної саморегуляції, само- та взаємодопомоги співробітників (працівників) правоохоронного органу (спеціальної служби, силової структури) в екстремальних умовах;

- психологія груп, команд, підрозділів правоохоронного органу (спеціальної служби, силової структури) та управління ними під час дій в екстремальних умовах;

- психодіагностика, профілактика та корекція негативних психічних станів, що виникають у співробітників (працівників) правоохоронного органу (спеціальної служби, силової структури) під впливом особливих умов;

- психологічна допомога співробітникам (працівникам) правоохоронного органу (спеціальної служби, силової структури), які пережили психотравмувальний вплив у процесі виконання професійних обов'язків;

- психологія після екстремальної роботи зі співробітниками (працівниками) правоохоронного органу (спеціальної служби, силової структури);

- психологічна реабілітація співробітників (працівників) правоохоронного органу (спеціальної служби, силової структури).

Уважаємо, що за аналогією можна виділити не тільки загальні проблемні області психології діяльності в особливих умовах з іншими спеціальностями психологічної науки, але й визначити міждисциплінарні зв'язки.

На основі тематичного аналізу назв і авторефератів дисертацій за період з 1992 по 2021 pp. за науковими галузями (за винятком психологічних наук) можливо констатувати, що проблеми психології діяльності в особливих умовах розглядалися в дисертаціях за такими науковими галузями:

1. Біологічні науки $(03.00 .13$ - «Фізіологія людини і тварин»; 03.00.16 - «Екологія»).

2. Технічні науки (05.01.04 - «Ергономіка»; 05.26.01 - «Охорона праці»).

3. Філософськи науки (09.00.03 - «Соціальна філософія та філософія історії»; 09.00.05 - «Історія філософії»; 09.00.11 - «Релігієзнавство»).

4. Історичні науки (07.00.01 - «Історія України»; 07.00.07 - «Історія науки і техніки»; 07.00.09 - «Антропологія»).

5. Юридичні науки (12.00.09 - «Кримінальний процес та криміналістика; судова експертиза; оперативно-розшукова діяльність»; 12.00.11 - «Міжнародне право»).

6. Педагогічні науки (13.00.01 - «Загальна педагогіка та історія педагогіки»; 13.00.02 - «Теорія та методика навчання»; 13.00.04 - «Теорія і методика професійної освіти»; 13.00.05 - «Соціальна педагогіка»; 13.00.07 - «Теорія і методика виховання»).

7. Медичні науки (14.01.16 - «Психіатрія»; 14.01.33 - «Медична реабілітація, фізіотерапія та курортологія»; 14.02.03 - «Соціальна медицина»).

8. Військові науки $(20.02 .20-$ «Теорія стрільби»; 20.02.22 - «Військова історія»).

9. Національна безпека (21.01.01 - «Основи національної безпеки держави»; 21.02.01 - «Воєнна безпека держави»; 21.02.02 - «Охорона державного кордону»; 21.02 .03 - «Цивільний захист»; 21.03 .01 - «Гуманітарна і політична безпека держави»;21.06.02-«Пожежнабезпека»; 21.07.02-«Розвідувальна діяльність органів державної безпеки»; 21.07 .03 - «Кадри органів та військ державної безпеки»; 21.07 .04 - «Оперативно-розшукова діяльність»; 21.07 .05 - «Службово-бойова діяльність сил охорони правопорядку»).

10. Соціологічні науки (22.00.03 - «Соціальні структури та соціальні відносини»).

11. Державне управління (25.00.05 - «Державне управління у сфері державної безпеки та охорони громадського порядку»).

Отже, можна стверджувати, що проблеми психології діяльності в особливих умовах зачіпають практично всі розділи знань.

Висновки. Спеціальність 19.00.09 - «Психологія діяльності в особливих умовах» була і залишається важливою сферою наукового знання.

Проведений нами аналіз генези даної спеціальності дозволив: 
1. Визначити проблемне поле спеціальності (особливості дій фахівців в екстремальних ситуаціях, вплив екстремальних ситуацій на фахівців, професійно-психологічний відбір та екстремально-психологічна підготовка спеціалістів, психологічна готовність до дій в екстремальних умовах тощо).

2. Представити коло професій, які входять до предметної області спеціальності, як-от: пожежні, рятувальники, співробітники правоохоронних та спеціалізованих органів, військовослужбовці, космонавти, пілоти, моряки, охоронці, шахтарі, водії, спортсмени, працівники АЕС, особи, що стали жертвами подій, пов’язаних зі специфікою професійної діяльності зазначених фахівців.

3. Виявити міждисциплінарні зв'язки спеціальності 3 біологічними, технічними, історичними, юридичними, педагогічними, медичними, військовими, соціологічними науками, національною безпекою та державним управлінням.

Перспективу дослідження вбачаємо в більш грунтовному опрацюванні здобутків спеціальності 19.00.09, метою якого $є$ не тільки вирішення методологічних проблем, але й висвітлення провідних та перспективних наукових напрямів у межах заявленої спеціальності.

\section{Список літератури:}

1. Про затвердження переліку спеціальностей наукових працівників : наказ ВАК України від 13.03 .1997 p. № 86. URL: https://zakon.rada.gov.ua/laws/show/z0133-97\#Text (дата звернення: 22.09.2021).

2. Про затвердження переліку спеціальностей, за якими проводиться захист дисертацій на здобуття наукових ступенів кандидата наук і доктора наук, присудження наукових ступенів і присвоєння вчених звань : наказ ВАК України від 10.06.1999 р. № 288. URL: http://search.ligazakon.ua/1_doc2.nsf/link1/REG3718.html (дата звернення: 22.09.2021).

3. Паспорти спеціальностей - Психологічні науки. URL: https://www.studmed.ru/pasporti-specalnosteypsihologchn-nauki_b6b2535a816.html (дата звернення: 22.09.2021).

4. Перелік галузей знань і спеціальностей, за якими здійснюється підготовка здобувачів вищої освіти : постанова Кабінету Міністрів України від 29.04.2015 p. № 266. URL: https://zakon.rada.gov.ua/laws/show/266-2015-\%D0\%BF\#Text (дата звернення: 22.09.2021).

5. Елисеева И. История развития отечественной экстремальной психологии : дис. ... канд. психол. наук: 19.00.01. Москва, 2015. 286 с.

6. Климов Е. Школа... а что дальше? Старшекласснику о выборе профессии. Ленинград : Лениздат, 1971. $190 \mathrm{c}$

\section{Shashenkov D.M. GENESIS SPECIALTIES 19.00.09 - "PSYHOLOGY OF ACTIVITY IN SPECIAL CONDITIONS"}

The article is aimed at disclosing the historical progress of the specialty 19.00 .09 - "Psychology of activity in special conditions" and scientific achievements obtained by researchers within its limits, as well as consideration of methodological problems that have been ignored by scientists. When considering the generalization of the specialty 19.00 .09 used: the method of thematic classification of dissertations, content analysis, synthesis and review and analytical method. These methods allowed to identify and characterize: problem field of the specialty (peculiarities of actions of specialists in extreme situations, influence of extreme situations on specialists of the security and defense sector, their professional and psychological selection, extreme psychological training, as well as features of self-regulation; psychodiagnostic, psychoprophylactic and rehabilitation work with relevant specialists, establishing their psychological readiness for action in extreme conditions, as well as psychological assistance to employees who have experienced a psycho-thrasing effect in the process of performing professional duties; peculiarities of interaction of specialists with citizens who are in a changed, crisis or threatening mental state, psychology of prevention and termination of group violations of public order and riots) and interdisciplinary connections of psychology of activity in special conditions (with biological, technical, historical, legal, pedagogical, medical, military, sociological sciences, national security and public administration), the range of professions to which the results of research in the above-mentioned specialty (firefighters, rescuers, law enforcement and specialized authorities, military personnel, astronauts, pilots, sailors, guards, miners, drivers, athletes). The prospect of further research is seen in a more thorough study of the achievements of the specialty "Psychology of activity in special conditions", the purpose of which is not only to solve methodological problems, but also to highlight leading and promising scientific directions within the declared specialty.

Key words: psychology of activity in special conditions, methodology, dissertation research, security and defense sector of Ukraine, thematic classification. 